\title{
Islamic Human Resource Management Practices and Innovation in Malaysian Public Service
}

\author{
Ilhaamie Abdul Ghani Azmi \\ University Malaya \\ ilhaamie@yahoo.com
}

\begin{abstract}
The contribution of Islamic human resource management practices (IHRM) on enhancing innovation has not been researched yet in Malaysian public service. Moreover, one of IHRM practices which is Islamic promotion practice has not been studied in previous researches. Thus, this is the impetus of this study. As many previous studies have engaged quantitative method in attaining their research objectives, this study tries to contribute to the body of knowledge by engaging qualitative method whereby semi-structured interviews are conducted with the top management and exec-utives of ten public agencies. Five interviews are allocated to each awarded and non-awarded public organizations. The purpose is to examine the similarities and differ-ences of these public agencies and between different types of informant. The results found similarities and differences among the awarded and non-awarded public agen-cies. The result shows that majority of the awarded public organizations agreed that the implementation of IHRM practices in the organizations has enhanced innovation. The findings of this study indicate that IHRM practices should continue to be imple-mented in Malaysian public service as it contributes to increasing innovation at the workplace.
\end{abstract}

Keywords: Islamic Human Resource Management, Innovation, Public Service, Award, Malaysia. 


\section{Islamic Human Resource Management Practices and Innovation in Malaysian Public Service}

\section{Introduction}

Islam is Malaysia's official religion. Hence, Malaysia tries to instil Islamic values as the way of life and also as work values in Malaysian public organizations. Tun Mahathir, the current Prime Minister has propagated this when he was the fourth prime minister and until today, the values have been upheld at the public service. His motto; Bersih (clean), Cekap (competent) and Amanah (trustworthy) is still well known today.

The OECD in 1995 suggested that the traditional public service approach to human resource management (HRM) is a major impediment to performance as organizations are "highly-centralized, rule-bound, and inflexible" with a focus on process rather than performance. Thus, HRM could be more effective in enhancing innovation performance if organizations have different HR practices for different groups of individuals (Paauwe \& Boselie, 2005). This seems to be feasible especially in Malaysia which is a multi-ethnic country, whereby majority of its population is Muslim and the rest is non-Muslims which include Christian, Buddhists and Hindus. Henceforth, its government will be more effective and efficient especially when implementing Islamic human resource practices in the public sector.

Innovation is pertinent in order to enhance public service delivery, productivity and citizen satisfaction. Malaysian government has taken many initiatives to promote innovation in the public sector in order to transform the public sector towards world class public service. For example, e-Government initiatives were introduced such as myGov Portal, ePerolehan, e-Syariah and e-Tanah. The agenda of innovation was continued in the Tenth Malaysia Plan (2010-2015) through various innovative policy initiatives implementation such as Agensi Inovasi Malaysia (2010), 


\section{Ilhaamie Abdul Ghani Azmi 52}

Circular on Guidelines to Enhance Culture of Innovation in Public Sector (2010), Innovating Malaysia Framework (2011), Public Sector Innovation Hub (2011), Public Sector Innovation Day (2012), Public Sector Transformation Initiatives (2012), and the National Science, Technology and Innovation Policy (2015). However, due to unclear policies, redundancy of authority, budget constraints and absence of a systematic monitoring system, the implemented policy failed to achieve the aspired objectives (Ramli et al, 2017).

One of the initiatives also includes awarding the most innovative public organizations. Certain criteria need to fulfill such as practicing innovative human resource management like IHRM practices. Thus, there is a need to study how IHRM practices can facilitate innovation. This is the impetus of this study. This article will be divided into four main parts which are literature review, methodology, results, discussion, conclusion and recommendation.

\section{LITERATURE REVIEW}

\section{Islamic HRMP practices and Innovation}

In most Muslim countries like Indonesia, Malaysia, Brunei and Middle East whereby Islam is the national religion, Islamic principles are embedded into HRM. Islamic HRM (IHRM) is based on Quran and Hadith of Prophet Muhammad (Hadjri, Perizade, Marwa \& Hanafi, 2018). Thus, some scholars name it as Quran based HRM (Hashim, 2008; Siswanto, 2014). IHRM practices are unique as they are applied both to the employer and also employees. This affirms that Islam is the way of life. As Muslims, they have to submit to their religion in all aspects of life. This is because Islam does not only focus on worldly affairs but also Hereafter. 


\section{Islamic Human Resource Management Practices and Innovation in Malaysian Public Service}

This means that besides performing their obligatory religious duties such as performing prayer, fasting and paying zakat (tithe), Muslims have to abide to Islamic principles in their daily life either at home or workplace. Henceforth, Islam is a complete religion. It encompasses religious rituals as well as daily activities and work life.

In Islam, human is the vicegerent of the earth. He or she is responsible in controlling and monitoring resources and assets on this earth including other human being. Unlike other kind of resources, there are certain processes and practices that employers need to abide to in dealing with human assets. This is because human resource is the organization's main asset at the workplace. In other words, knowledge, skills and ability that are possessed by employees are the human capital at the workplace that the employers need to protect as they are precious and rare.

Islamic human resource management practices are defined as the management of human capital across organizations upon Islamic principles through various practices at the workplace (Fesharaki \& Sehhat, 2017). IHRM practices can be described as the activities of the organization that involve the management of the groups of human resource and making sure that their management is aligned to the goals of the organization i.e. innovation and attaining the pleasure of God at the same time based on Islamic principles. IHRM practices can foster the innovative abilities of employees. IHRM practices which are capable of developing innovation and creativity in employees are considered important for the success of an organization.

According to Alkahtani (2014), there are seven principles of Islamic values which are embedded into HRM such are niya (intention), ta- 


\section{Ilhaamie Abdul Ghani Azmi 54}

$q w a$ (piety), ehsan (kindness), adl (justice), amanah (trust), sidq (truthfulness), itqan (perfection), ikhlas (sincerity), shura (consultation) and sabr (patience). Ahmad (2008) elaborates this further into personal (piety) and organizational values which are categorized into akhlaq and itqan. Personal values are like Trustworthiness (Ittimaniyyah), Justice (Adalah), Sincerity (Ikhlas), Honesty (Amanah), Gratefulness (Syukur) and Courage (Shujaah). While akhlaq values are like Caring (Ihtimam), Cooperation (Ta'awun/Musa'adah), Courtesy (Mulathofah/Adab), Humility (Tawaduk/Wadho'ah), Tolerance (Tasaamuh) and Respect (Ihtiram/Ri'ayah). On the other hand, itqan values are Effectiveness (Syiddah al- Maf'ul), Efficiency (Iqtidar/Fa'aliyyah), Innovativeness (Tajdid/Ihdath), Discipline (Intidzam), Commitment (Iltizam/Iida'), Learning (Ta'allum). Thus, innovation or innovativeness is the itqan value. However, we feel that itqan is not only at the organizational level but it also can be located at the individual level. Thus, other than piety at the individual level, Muslims need other personal values such as itqan in order to innovate (Ahmad \& Allen, 2015).

Instillation of Islamic values in Malaysian public sector has long been practiced since Tun Mahathir was the Prime Minister in 1985. There are 11 Islamic values propagated by him which are Amanah (trustworthy); Tanggungjawab (responsibility); Ikhlas (honesty); Dedikasi (dedication); Sederhana (moderation); Tekun (hardworking); Bersih (clean); Berdisiplin (disciplined); Bekerjasama (Cooperative); Berbudi Mulia (virtous); and Bersyukur (thankfulness) Later, Tun Ahmad Badawi took the helm as the Prime Minister and Islamic Hadhari was being practiced in late 2003. Islam Hadhari postulates ten fundamental principles which are faith and piety in God, just and trustworthy Government, free and independent people, 


\section{Islamic Human Resource Management Practices and Innovation in Malaysian Public Service}

vigorous pursuit and mastery of knowledge, balanced and comprehensive economic development, good quality of life for the people, protection of the rights of minority groups and women, cultural and moral integrity, safeguarding natural resources and the environment, as well as strong defense capabilities (Hashim, 2010). When Dato' Seri Najib Razak replaced Tun Ahmad Badawi later, he introduced the concept of moderation (wasatiyyah).

Regarding to the dimension of IHRM practices, the authors in this field differ. According to Hadjiri et al. (2019), IHRM comprises of Islamic recruitment and selection, Islamic training and Islamic compensation. Muafi, and Qurotul Uyun (2018), alKahtani (2018), Nik Ab, Rahman, Shahid and Alam (2011) stated that there are four dimensions which are compensation, selection, training, performance assessment, whereas Azmi (2010; 2015), Hashim (2009) and Namazie and Tayeb (2006) mentioned that there are five IHRM which are selection and recruitment, training and development, career development, performance management and reward. Osman, Mahphoth and Hashim (2012) also agreed that IHRM activities include recruitment and selection, training and development, career development, performance management and rewards. Siswanto (2014) also concurred that Quran-based human resource management practices include the activities of recruitment, selection, performance appraisal, education and training, and compensation. However, Rana Riaz Ahmad (2015) added one more dimension to his study which is employee participation.

The extent of implementation of IHRM practices also differs. Azmi in 2010 has found two Islamic human resource practices were being implemented in Malaysian Islamic organizations to a considerable extent which are recruitment and selection and training and development. The 


\section{Ilhaamie Abdul Ghani Azmi 56}

other practices such as career development, performance measurement and reward are implemented moderately. The overall implementation of Islamic human resource practices in Malaysian Islamic organizations is moderate. The Islamic organizations are categorized into public, private and NGOs. Difficulties in implementation could be the factor. Her finding concurs with Hashim (2010) except Hashim found another aspect of IHRM which was strictly observed in compensation.

There are several studies that attempt to find the relationship between IHRM practices and performance except for Mohd Said (2015) who just tried to find the relationship between demographic variables and IHRM practices. The findings of their studies are further elaborated as below.

Hadjiri et al. (2019)'s results showed that all variables IHRM namely; Islamic recruitment and selection, Islamic training, and Islamic compensation had a positive and significant effect on employee performance. They found that out of these three IHRM, Islamic recruitment and selection variable had the most influence on employee performance with a Beta value of 0.515, while the Beta value of Islamic training and Islamic compensation variables are 0.339 and 0.225 respectively. The regression results also reveal that the significance level of all IHRM variables is below 0.05 which indicates a significant effect on employee performance at Sharia Banks in South Sumatera Province.

Muafi, and Qurotul Uyun (2018) found that the relationship between IHRM practices and environmental, social and religious performance is mediated by organizational learning whereby innovativeness is a criterion in social performance in Batik SMEs in Pekalongan City, Central Java. Social welfare of communities in Pekalongan City, Central Java is 


\section{Islamic Human Resource Management Practices and Innovation in Malaysian Public Service}

very well kept by Batik SMEs. They assessed practices of Islamic human management resources through compensation, selection, employee training, performance assessment, and Islamic work ethics.

Kumar Dhar, Masruki, Mutalib, Mohammed Rahouma, Sobhani, Nurul Absar (2018)'s study demonstrated that Islamic HR practices have a more significant impact on organizational performance through organizational commitment rather than the direct effect of Islamic HR practices on organizational performance. This study adopted four dimensions of IHRM which are Islamic selection and recruitment, Islamic training and development, Islamic career development, and Islamic reward practices.

Kumar Dhar, Mohammed Rahouma, Masruki and Nurul Absar (2017)'s study found that IHRM practices have a significant impact on organizational performance (OP) through organizational commitment (OC). The impact on OC is similar to OP. They focus on four dimensions of IHRM practice which are Islamic selection and recruitment, Islamic training and development, Islamic career development, and Islamic reward practices.

Fesharaki and Sehhat (2017)'s study showed four dimensions of IHRM i.e. recruitment and selection, training and development, remuneration and compensation, performance appraisal are positively associated with organizational justice in a Qard Al-Hasan bank in Iran. Furthermore, the first three dimensions have a positive impact on employees' commitment but the link between performance appraisal and employees' commitment was not statistically significant which is due to the slightly negative attitude of the employees towards the results.

Ali Mahesar, Chaudhry, Ansari and Ali Nizar (2016) found IHRM is significantly and highly correlated to employee outcomes such as job 


\section{Ilhaamie Abdul Ghani Azmi 58}

satisfaction, turnover intentions and organizational commitment. The multiple regression analysis revealed that employee engagement mediated the relationship between IHRM and employee outcomes. They studied on five IHRM practices which are recruitment, selection, training and development, performance appraisal and compensation.

Rana Riaz Ahmad (2015) examined the moderating role of Islamic principles on the relationship of HRM practices and organizational performance in employees of mobile telecommunication service providers operating in Pakistan. He found that there is a strong moderating role of employee participation in the relationship.

Azmi (2015)'s study found that there is only one IHRM practice i.e. training and development practice which is positively and significantly related to organizational performance. She also found that Islamic selection and recruitment are practiced to a greater extent by the Islamic organizations in Malaysia.

Ahmad and Allen (2015) studied high-performance HR practices, such as extensive training, career breaks, rigorous pre-employment candidate assessment, and the sharing of strategic information with employees. They found that the provision of training in a variety of jobs to non-managerial employees is consistently associated with better HR-related outcomes such as absenteeism, quit rates, and labour productivity. Overall, their study finds some limited support for the applicability and efficacy of high-performance HRM practices in Pakistan. Such practices conform to Islamic principles. The results also indicate, however, that cultural traits play a role in how those practices are implemented. 


\section{Islamic Human Resource Management Practices and Innovation in Malaysian Public Service}

Mohd Said (2015) examined the factors that influence IHRM practices in Felda Holdings Bhd in Alor Setar. She studied five IHRM practices which are recruitment, selection, performance appraisal, training and development and compensation. She found that age showed no significant relationship to Islamic Human Resource Management practices among Muslim staff. For gender and level of education, it shows Muslim staff have a significant relationship to IHRM practices.

Osman, Mahphoth, Hashim and Omar (2014) found in their study that the relationship between Islamic human talents identification variables and organizational justice was strong in Malaysia's GLCs.

Siswanto (2014) stated that Quranic based HRM practices do not increase job satisfaction directly, but increase job satisfaction through the variable of organizational justice in Malang Islamic banking.

Nik Ab. Rahman, Alias, Shahid, Abdul Hamid and Alam (2013) mentioned in their study that knowledge, understanding and practices of Islamic principles, recruitment and selection, training and development, and reward system are significantly related to trust. However, performance appraisal practice is found to have an insignificant relationship in Bangladesh Islamic banks.

Nik Ab, Rahman, Shahid and Alam (2011)'s study findings revealed that IHRM explains about 40 percent of the variances in organizational commitment. All factors, except selection and recruitment practices were found to be significantly related to organizational commitment in Bangladesh Islamic banks.

Hashim (2010)'s findings demonstrated that the selected eight Islamic organizations in Malaysia frequently practice the Islamic approach in all its human resource management (HRM) functions. The results of 


\section{Ilhaamie Abdul Ghani Azmi 60}

correlation and regression analysis show that the Islamic approach in HRM was highly and significantly correlated to organizational commitment. About 45 percent of the organizational commitment variance was explained by the Islamic approach in HRM.

Azmi (2010) found the impact of IHRM practices on organizational performance in Malaysian Islamic organizations is considerable. This shows that Islamic human resource practices are better than the conventional perspective in producing higher organizational performance. These Islamic organizations implement Islamic human resource practices due to Islam; the religion is the way of life, type or nature of their organizations and organizational mission.

Hashim (2008)'s finding showed three facets of organizational justice and job satisfaction were highly and significantly correlated with Quran based HRM practices in Islamic organizations in Malaysia. There were five Quran based HRM practices tested in her study which are recruitment, selection, training and development, performance appraisal and compensation practices.

Henceforth, there are several studies that are conducted on the relationship of IHRM and outcomes and performance either at the employees' level or organization. However, there is a dearth of studies done on promotion as IHRM practice and innovation as an aspect or dimension of performance. Alkahtani (2014) for example, has not tested the relationship empirically. Whereas Muafi, and Qurotul Uyun (2018) measured innovativeness as a dimension of social performance in SMEs. Moreover, there are many quantitative studies done on the private sector in finding the relationships of IHRM and its output especially performance. Thus, this is 


\section{Islamic Human Resource Management Practices and Innovation in Malaysian Public Service}

the impetus of this study to examine the relationship of IHRM and innovation in the public sector by using qualitative method.

\section{Islamic Recruitment and Selection Practice}

Islamic recruitment and selection is a practice to select and recruit employees based on Islamic principles. Adalah or just is the principle for the employer to uphold in this process especially in choosing and making the decision of the potential employees. As Allah says in Surah an-Nahl, verse 90: "Indeed, Allah commands justice, grace, as well as courtesy to close relatives. He forbids indecency, wickedness, and aggression. He instructs you so perhaps you will be mindful." Honesty is also another requirement in recruitment and selection whereby the criteria of potential employees should be disseminated through advertisement either internally or externally and final results of the process should be informed to the candidates regardless of whether they are successful or not. This emphasis can be seen in Surah Tawbah, verse 119 which means "O believers! Be mindful of Allah and be with the truthful". Employees, on the other hand, should be honest about their qualifications, skills and experience. There are many criteria of a potential candidate which can be categorized into two main components which are competencies and akhlaq. The competencies can be divided further into knowledge, hard skill and abilities which constitute the qualification of the employees while akhlaq or manners are soft skills such as teamwork, dedication, commitment, hardworking, trustworthy, loyal and disciplined (Azmi, 2010). Prophet Muhammad is our idol in Islam. As in Surah Qalam, verse 4 which means "And indeed, you are of a great moral character." By possessing these competencies and 


\section{Ilhaamie Abdul Ghani Azmi 62}

the right attitudes, public servants will be more innovative in their work in order to enhance the quality of the services rendered to the citizens.

\section{Islamic Training and Development Practice}

Islamic training and development practice focuses on training employees' intellectuality, spirituality, emotionally and physically. In short. Islamic training and development practice acknowledges human components of mind, physical and spiritual. To gain knowledge whether it is revealed (naqli) or acquired (aqli) is the responsibility of all Muslims (Sunan Bukhari, Yusof \& Sari, 2017). It is opposite to conventional training and development which do not stress on the spiritual aspect of employees. This brings to the responsibility of the employers as the guard keeper. They should not think too much about the profitability of their firm without looking after their employees. This is in line with the principle of corporate social responsibility. In fact, employers have to be fair to their employees in ensuring that every one of them deserves training. Thus, Islamic methods of training like sermons (tazkirah), discussion of the Islamic principles in view of Quran and Hadith (Prophet's prescriptions), congregational prayers can be utilized in the organization (Azmi, 2010). Through this Islamic training and development practice, pious employees will be produced who will ensure that they are innovative in their work as required by their employer. This can be seen in Surah al-Bayyinah, verse 9 which means "Indeed, those who believe and do good — they are the best of 'all" beings". This is important in order to enhance service quality in the public sector. 


\section{Islamic Human Resource Management Practices and Innovation in Malaysian Public Service}

\section{Islamic Performance Management Practice}

Islamic performance management is a practice to manage and evaluate the performance of Muslim employees based on Islamic principles and values. Islam is a religion that strongly emphasizes on performance at all levels whether it is individual or organization. This is because Islam ordains that every single deed is accountable even at the workplace. Islam denotes that the employer needs to be just and fair in appraising his subordinates and cannot oppress them out of hate and respite. In short, equal treatment should be given to every employee regardless of their identity and status. If the organization's objectives are not achieved, perhaps, it is not the mistake of the employees but could be due to the employer's mismanagement themself. Thus, the employer needs to spend time well on planning and to be systematic in its implementation. A whole year is given for this activity and the employers need to plan wisely and implement it carefully. Islam looks upon time management so much that the emphasis is mentioned in Surah al-Asr which means "By time. Surely humanity is in grave loss, except those who have faith, do good, and urge each other to the truth, and urge each other to perseverance." Henceforth, as employees, they have to carry out their duties diligently as this is their employer's trust. This can be observed in Surah Tawbah, verse 105 which means "Tell them, O Prophet, Do as you will. Your deeds will be observed by Allah, His Messenger, and the believers. And you will be returned to the Knower of the seen and unseen, then He will inform you of what you used to do." Henceforth, by being equitable, fair and just in appraising innovation in public servants' work, employees will be motivated and committed to producing innovative work. Furthermore, employers will send the message 


\section{Ilhaamie Abdul Ghani Azmi 64}

to the organization that innovation is the core of their work and this will be disseminated and socialized throughout the organization.

\section{Islamic Reward Practice}

Islamic reward is a practice to reward employees based on Islamic principles and values. Just is also a principle in Islamic reward practice whereby the reward should be sufficient based on the criteria of the employees such as qualification, experience and the amount of work that they do (Azmi, 2010). Other than these, quality of work in terms of innovation should also be rewarded. In short, quality and quantity are the two factors that employers should take into account in rewarding their employees (Hashim, 2010). The importance of quality can be seen in Surah Ahzab, verse 21 which means "There has certainly been for you in the Messenger of Allah an excellent pattern for anyone whose hope is in Allah and the Last Day and [who] remembers Allah often." Employees have put trust in their superiors and employers to return to what they have given to them in terms of knowledge, skills, abilities, time, effort, tears and sweat in ensuring that the tasks entrusted to them are completed and goals are accomplished. In return, the employers have reaped revenues and profits from the completed tasks that employees had carried out. Furthermore, the differential in wages based on favoritism, nepotism, and demographics of employees is strictly prohibited (Alkahtani, 2018).

\section{Islamic Promotion Practice}

Promotion is another aspect besides reward which they are looking for from their employers. In return for being loyal and committed to the 


\section{Islamic Human Resource Management Practices and Innovation in Malaysian Public Service}

workplace, employees need life-long and successful careers. Islamic promotion is a practice in promoting Muslim employees based on Islamic principles and values. Just and fairness are also the principles in Islamic promotion whereby the employees should not be discriminated or bypassed in pursuing their career. Most importantly, employers or superiors need to motivate their employees to be pursuant in chasing their dreams and ambition. This is important as the employees have their own dependents to support. Thus, employers need to have mercy and kindness (ehsan) in their hearts. This is the responsibility of khalifah (vicegerent) as they have to look after their people. As in Surah Baqarah verse 30 which means 'Remember' when your Lord said to the angels, "I am going to place a successive 'human' authority on earth.” They asked 'Allah", "Will You place in it someone who will spread corruption there and shed blood while we glorify Your praises and proclaim Your holiness?” Allah responded, "I know what you do not know'.

\section{Innovation}

Innovation in the public sector is defined as a process of creating, developing and implementing ideas to fulfill the public needs and demands (Mulgan, 2014). Innovation is considered as a process, result, or both, and different types of innovation have been distinguished. It can be a new system, policy, program, device, process, product or service for the organization (Heksarini, 2017). Dehghanian (2017) added organizational innovation which refers to the development or acceptance of a new idea or behaviour in business operation. In this study, technology, administrative and policy are also considered as innovation in public service. 


\section{Ilhaamie Abdul Ghani Azmi 66}

According to Dehghanian (2017), there are three phases of organization innovation which are innovation production, improvement and execution. Innovation production refers to presenting new ideas for job improvement, using new methods, new work techniques and coming up with new solutions. Innovation improvement refers to stimulating innovative ideas. Finally, innovation execution refers to turning the innovative thought to useful methods.

There are three ways that innovation is measured, firstly as performance, secondly as culture and thirdly as a business strategy. In this study, innovation is measured as performance whereby it is the output or outcome of the implementation of IHRM practices.

\section{Theoretical Framework}

In Islam, conventional theories such as AMO theory and social exchange theory are accepted in innovation study as far as they do not transgress the Islamic principles or known as Shariah. AMO theory suggests that HRM practices such as training and development enhance the organization's human capital via increased human capabilities that translate into performance outcomes such as innovation. While innovation-focused recruitment and selection and performance appraisal can ensure the required ability and capability for organizational innovation.

Meanwhile, social exchange theory (Blau, 1964) exerts that employees are viewed as perceiving HR practices such as reward and promotion as signals of the organization's responsibility towards them. If employees perceive the organization as providing value, they will feel obliged to reciprocate with something of value (Masterson, 2001) such as by helping the organization in reaching its goals. 


\section{Islamic Human Resource Management Practices and Innovation in Malaysian Public Service}

On top of these theories, Islamic theories such as vicegerent, ibadah and success in this world and hereafter (known as al-falah) are very well known in Islam which is attributed to Imam Yusuf al-Qardawi. It is believed that every mankind in Islam is a vicegerent and they are leaders in their own way. Thus, they have to make the best in everything even at the workplace is considered as ibadah (religious obligation), provided that they have the intention to do good deeds in order to be successful in this world and Hereafter which is known as al-falah.

\section{RESEARCH DESIGN}

This study engaged qualitative research design in achieving the research objectives. More than half of the studies on IHRM and performance that we found were using the quantitative method. Qualitative studies were less common. Henceforth, this study engaged qualitative multiple case study designs. The case studies consist of data collection through document studies and interviews of top management and executives of awarded and non-awarded public organizations.

Four IHRM practices investigated in this study were training and development, performance evaluation, reward and promotion that are linked with innovation in the Malaysian public sector. Semi structured interview was adopted in this study as the data collection method. Interview questions were developed based on past studies. Five public organizations from different agencies in the Malaysian public sector were chosen based on this criterion; (a) won innovation award locally or internationally while the other five did not have these criteria at all. The objective was to compare these two types of public organizations in order to examine the IHRM factors that support innovation. 


\section{Ilhaamie Abdul Ghani Azmi 68}

For the data analysis, two methods were identified which are thematic and content analysis. Thematic analysis is referred to as a method for identifying, analyzing and reporting patterns (themes) within the interview data. Purposive sampling method was used for selecting the participants for the interview. Semi structured interview was used in designing the research instruments whereby the interview questions are not fixed but flexible for the researcher as they are only used as guiding the interview process. The interview responses are transcribed and analyzed to identify themes, categories and patterns in the data.

Content analysis is referred to as the method of identifying, analyzing and reporting content within the secondary data such as documents, article journals, book chapters and others. This method was used to triangulate the findings obtained from the interviews which are the primary data. This is important in order to ensure that the data obtained from the primary data is highly reliable. This is because using only one data analysis method is not free from biases and inaccurate answers.

The results then were compared between the top management and executives to examine the differences of their understanding on the subject matter. The results were also compared between the awarded and nonawarded public organizations.

\section{FINDINGS AND DISCUSSION}

Table 1: Understanding of IHRM Practices among Top Management

\begin{tabular}{|l|l|}
\hline $\begin{array}{l}\text { Understanding of IHRM Practices } \\
\text { (Top Management) }\end{array}$ & \\
\hline Award & Non-Awarded \\
\hline
\end{tabular}


69 Islamic Human Resource Management Practices and Innovation in Malaysian Public Service

\begin{tabular}{|c|c|}
\hline $\begin{array}{l}\text { We allow employees to pray timely. } \\
\text { We have no problems regarding em- } \\
\text { ployees' relation. }\end{array}$ & $\begin{array}{l}\text { We do not do specifically for Islamic } \\
\text { practice. }\end{array}$ \\
\hline $\begin{array}{l}\text { In recruiting male workers, they are } \\
\text { asked to recite common surahs and } \\
\text { qunut and Islamic knowledge. We } \\
\text { also hold funeral prayers for dead em- } \\
\text { ployees, religious talk once a month } \\
\text { whereby the title of the talk is accord- } \\
\text { ing to the festive. Only in Rejab } \\
\text { month, we recite Surah Yassin after } \\
\text { prayer. }\end{array}$ & $\begin{array}{l}\text { Work hard every single minute. No } \\
\text { need to put Islamic in front. }\end{array}$ \\
\hline $\begin{array}{l}\text { Fair and equity and the quality of Is- } \\
\text { lamic leadership. }\end{array}$ & $\begin{array}{l}\text { I think it is more of what God is call- } \\
\text { ing and the Apostles are saying. One } \\
\text { of them is integrity. We cannot con- } \\
\text { tradict what our system does. For ex- } \\
\text { ample, the assessment system should } \\
\text { be fair. }\end{array}$ \\
\hline $\begin{array}{l}\text { We make Islam an indicator in recruit- } \\
\text { ment, placement, appraisal and so on. } \\
\text { Public servant is a trustee, he/she must } \\
\text { be dedicated to his or her job. For ex- } \\
\text { ample, giving appraisal mark in its } \\
\text { place. Concept of kindness, we be- } \\
\text { lieve God sees us. We need to make } \\
\text { our work as worship, so we will not } \\
\text { break the boundaries. }\end{array}$ & $\begin{array}{l}\text { Salaries are paid through Islamic } \\
\text { banking. Nawaitu. }\end{array}$ \\
\hline $\begin{array}{l}\text { Pure values e.g. trust, responsibility, } \\
\text { time management, everything is from } \\
\text { Islam. Everything we do is Islamic. } \\
\text { Each morning we begin with recita- } \\
\text { tion of supplication prayers and Surah } \\
\text { Fatihah, intention of work. Friend- } \\
\text { ship, close brotherhood. }\end{array}$ & $\begin{array}{l}\text { Implementing Islamic values in fi- } \\
\text { nance, procurement, administration } \\
\text { and others. }\end{array}$ \\
\hline
\end{tabular}

The managers of awarded public organizations admitted that they inculcated the Islamic values in their workplace especially in HRM practices such as recruitment and selection, placement, performance appraisal and other management practices. This is supported by Hashim (2008, 


\section{Ilhaamie Abdul Ghani Azmi 70}

2009, 2010)'s finding that IHRM practices are frequently implemented in her selected Islamic organizations in Malaysia and Siswanto (2014) in Islamic banks in Malang especially in compensation practice. Similarly with Nik Mutasim et al (2013)'s study in Islamic banks in Bangalesh, IHRM practices are known, understood and practiced by them particularly training and development practices.

The Islamic values mentioned by the managers of awarded public organizations are fair, equity, ehsan, trust, dedication, kindness, responsibility, time management and teamwork (brotherhood or friendship). This is supported by Ahmad and Allen (2015) that these Islamic principles especially ehsan emphasize equal treatment and consideration of human aspects in HR practices. At the same time, Bachkirov and Mohd Shamsudin (2017) agreed with equity or distributive justice in reward allocation in Arab-Islamic organizations in Oman. Siswanto (2014) concurs with fairness that is categorized in three which are procedural, distributive and interactional in compensation practice in Islamic banks in Malang. Thus, these values are important as they can solve the problems of discrimination and subsequently, harmony will be sustained at the workplace.

The awarded public organizations also used Islamic methods in training which are congregation prayers, reciting Quran, supplication and religious talk or discussion. They also are aware of Islamic concepts such as nawaitu (good intention), ibadah (work objective), leadership and employee welfare or known as corporate social responsibility. This is supported by Muafi and Uyun (2018)'s study that religious activities such as performing ritual prayers in congregation, following regular religious studies, performing social finance (sodaqoh) and other religious activities 


\section{Islamic Human Resource Management Practices and Innovation in Malaysian Public Service}

if are conducted regularly and sincerely will bring satisfaction, peace, and happiness in life

However, the non-awarded public organizations stated that they did not implement any Islamic practices and there is no need of putting the name of Islam in front of any practice. This is because doing so, according to them, will scare other people off especially non-Muslim. This is true as Malaysia is a multi-ethnic country and non-Islamic organizations do not particularly name their practices as Islamic. However, universal values do not transgress with Islamic values. Thus, there is no big gap between the IHRM and non-IHRM practices except the faith of the employees (Junaidah, 2008; 2010; Habib, 2015). Only two of them really understand and mentioned that they instill the Islamic values in performance assessment, finance, procurement, administration and others. One of the interviewees also understands the term nawaitu which is important in order to ensure that Allah will accept their work as good deeds or ibadah.

Table 2: Understanding of IHRM Practices among Executives

\begin{tabular}{|c|c|}
\hline IHRM Practices (Executive) & \\
\hline Awarded & Non-Awarded \\
\hline $\begin{array}{l}\text { Prefer recruiting women with head- } \\
\text { scarves and body covering. }\end{array}$ & MS 1900. \\
\hline Wearing formal attire for training. & Shariah Compliance Panel \\
\hline $\begin{array}{l}\text { Relationships between men and } \\
\text { women are monitored. }\end{array}$ & $\begin{array}{l}\text { Always celebrate religious days such } \\
\text { as the prophet birthday, Israk \& } \\
\text { Mikraj. }\end{array}$ \\
\hline $\begin{array}{l}\text { Religious talk every month and every } \\
\text { day during Ramadhan. }\end{array}$ & $\begin{array}{l}\text { Implement good work culture based } \\
\text { on Islamic principles. }\end{array}$ \\
\hline $\begin{array}{l}\text { Responsible, trustworthy, time man- } \\
\text { agement, disciplined, integrity. }\end{array}$ & $\begin{array}{l}\text { The application of pure values in all } \\
\text { HRM practices. For example, dedica- } \\
\text { tion in attendance, integrity, perfec- } \\
\text { tion, responsible, trustworthy, time } \\
\text { management, disciplined, honesty. }\end{array}$ \\
\hline
\end{tabular}




\section{Ilhaamie Abdul Ghani Azmi 72}

\begin{tabular}{|l|l|}
\hline $\begin{array}{l}\text { Recite Quran during the break. Recite } \\
\text { Surah Yassin, Kahfi }\end{array}$ & $\begin{array}{l}\text { Recite Surah Yassin especially on Fri- } \\
\text { day }\end{array}$ \\
\hline Dhuha and Hajat prayers. & Akhlak \\
\hline $\begin{array}{l}\text { Employee welfare (e.g. death, school } \\
\text { going children) Pregnant women can } \\
\text { return home early } 1 \text { hour before clos- } \\
\text { ing time. }\end{array}$ & \\
\hline $\begin{array}{l}\text { Recite supplication early morning, } \\
\text { Asmaul Husna at 2 pm and another } \\
\text { supplication recitation before going } \\
\text { back at 5 pm by using the microphone }\end{array}$ & \\
\hline
\end{tabular}

When the executives were asked about their understanding of IHRM practices, majority of both public organizations understand what they are. However, the non-awarded public organizations mentioned that there are no specific values for Islamic human resource management as they are more familiar with the Malay names such as amanah (trustworthy), bersih (clean) and cekap (competent). This is supported by Hashim (2009)'s finding that 40 percent of her respondents are not sure of what IHRM practices are as they do not understand the difference between IHRM and non-IHRM practices.

When the executives were asked particularly of IHRM practices, the common answer given by the awarded and non-awarded public organizations is the application of pure values in all HRM practices such as responsibility, trustworthiness, time management and disciplined. The awarded public organization gave one extra answer i.e. integrity while non-awarded mentioned three more Islamic values which are dedication, perfection, and honesty. The awarded public organizations provide so many other answers on the rest as compared to the non-awarded public organizations. This shows that the awarded public organizations are more 


\section{Islamic Human Resource Management Practices and Innovation in Malaysian Public Service}

aware of IHRM practices compared to the non-awarded public agencies such as recruitment, training and employee relation. They also mentioned the use of Islamic techniques in training such as congregation prayers, Quran recitation, religious talk or discussion and employee welfare. However, one of the non-awarded public organizations really practices IHRM in the sense that they observe Islamic ISO which is known as ISO 1900 and they also have Shariah compliance panels in order to ensure that their ministry really practices Islamic principles in their work procedures which include HRM practices. Akhlak or good manner is another principle in recruitment and selection and performance appraisal practices. Furthermore, they also use Islamic techniques in training such as Quran recitation and religious talk or discussion. This is supported by Nik Mutasim et al (2013) that trustworthiness is embedded in recruitment and selection practice and responsibility in reward and compensation practices in Islamic banks in Bangladesh.

The majority of the awarded public organizations mentioned that they implement the IHRM practices either directly or indirectly and innovation is embedded in the practices. Whereas the majority of the nonawarded public agencies mentioned that the Islamic HRM practices are implemented indirectly. This finding is supported by Ababneh and Axramenko (2016) in Jordan universities that IHRM practices are implemented explicitly, however; to a limited extent. Nik Mutasim et al (2011) also affirm this as an organization that is operated under Shariah or Islamic principles, should embed this in their HRM practices.

The majority of the managers of the awarded public organizations agreed that the implementation of IHRM practices in the organizations has enhanced innovation. However, the non-awarded public organizations are 


\section{Ilhaamie Abdul Ghani Azmi 74}

less agreed whereby two of them are somewhat agreed about this. However, there is one top management that mentioned innovation has been enhanced by the implementation from medium to a high level. Similarly, the majority of the executives of awarded public organizations agreed that IHRM practices really enhance innovation. However, this is opposite to the non-awarded public organizations. This finding is supported by Azmi (2010) that the impact of IHRM on organizational performance is considerable specifically in selected Islamic organizations. Thus, this holds the same for public organizations. Only one executive of the non-public organizations agreed to this whereas the other two stated that the impact is moderate. This finding is supported by Azmi (2010) who found that the implementation of IHRM in Islamic organizations is moderate. These Islamic organizations implement IHRM as Islam is their way of life, the status and mission of their organization Thus, if the IHRM implementation is moderate in the public organizations specifically the non-awarded, the impact on innovation is also moderate.

\section{CONCLUSION AND RECOMMENDATION}

It can be concluded that the majority of the awarded and nonawarded public organizations understand what IHRM practices are either the top management or the executives. Recruitment and selection is the most common IHRM practice that they understand. Moreover, the common pure values that they agreed inculcated in HRM practices are trustworthy, responsible, disciplined and time management. Furthermore, the majority of awarded public organizations agree that IHRM practices en- 


\section{Islamic Human Resource Management Practices and Innovation in Malaysian Public Service}

hance innovation either by the top management or the executives. However, the non-awarded public agencies either the top management or the executives are somewhat agreeing about this.

The findings show that both types of public agency somehow only know about what pure values are and not to understand what Islamic values are. This demonstrates that the propagation of Tun Mahathir is successful. In other words, his idea of integrating people in the public sector regardless of their ethnicity and religion is successful. However, the government has to do something especially JAKIM has to play its role in educating the public servants on this matter especially on the Islamic terms of the values as Muslims in Malaysia particularly need to know and be aware of these. The government also needs to implement IHRM practices extensively especially at the non-awarded public agencies. Perhaps by disseminating circulars on IHRM practices and implementation of tight enforcement could solve this matter.

\section{References}

Abdul Ghani Azmi, I. (2015). Islamic Human Resource Practices and Organizational Performance: Some Findings in A Developing Country. Journal of Islamic Accounting and Business Research, Vol. 6(1), 1-14.

Abdul Ghani Azmi, I. (2010). Islamic Human Resource Practices and Organizational Performance: A Preliminary Finding of Islamic Organizations in Malaysia. Journal of Global Business and Economics, Vol. 1(1), 27-42.

Ahmad, M. and Allen, M. (2015). High Performance HRM And Establishment Performance in Pakistan: An Empirical Analysis. Employee Relations, Vol. 37(5), $506-524$. 


\section{Ilhaamie Abdul Ghani Azmi 76}

Ababneh, H and Axramenko, A (2016). Impact of Islamic Values on HRM Practices: Empirical Studies of Jordanian Universities. International Journal of Business Excellence, Vol. 10(1), 1-19.

Bachkirov, A. A. and Mohd. Shamsudin, F. (2017). Reward Allocation Decision Making in Arab-Islamic Business Organizations: An Empirical Examination Through an Emic Lens, International Journal of Islamic and Middle Eastern Finance and Management, Vol. 10(4), 536-553.

Alkahtani, A. (2014). An Application of Islamic Principles in Building A Robust Human Resource Management System (In Islamic Countries). International Journal of Recent Advances in Organizational Behaviour and Decision Sciences (IJRAOB). An Online International Research Journal (ISSN: 2311-3197), Vol. 1(3), 183.

Fesharaki, F. \& Sehhat, S. (2017). Islamic Human Resource Management (IHRM) Enhancing Organizational Justice and Employees' Commitment: Case of A Qard Al-Hasan Bank in Iran. Journal of Islamic Marketing, 1-26.

Hadjri, M.I, Perizade, B., Marwa, T. \& Hanafi, A. (2019). Islamic Human Resource Management, Organizational Commitment and Employee Performance: A Case Study on Sharia Bank in South Sumatera. International Review of Management and Marketing, Vol. 9(1), 123-128.

Hashim, J. (2010). Human Resource Management Practices on Organisational Commitment: The Islamic Perspective. Personnel Review, Vol. 39(6), 785-799.

Hashim, J. (2008). The Quran-based Human Resource Management and Its Effects on Organisational Justice, Job Satisfaction and Turnover Intention. The Journal of International Management Studies, Vol. 3(2), 148-159.

Hashim, J. (2009). Islamic Revival in Human Resource Management Practices Among Selected Islamic Organizations in Malaysia. International Journal of Islamic and Middle Eastern Finance and Management, Vol. 2(3), 251-267. 


\section{Islamic Human Resource Management Practices and Innovation in Malaysian Public Service}

Heksarini, A. (2017). Knowledge Management Capability to Organizational Innovation Study at Indonesia Islamic Banking. Advances in Economics, Business and Management Research (AEBMR), 35.

Paauwe, J. and Boselie, P. (2005). HRM And Performance: What Next? Human Resource Management Journal, Vol. 15(4), 68-83.

Kumar Dhar, B., Masruki, R., Mutalib, M., Mohammed Rahouma, H., A. Sobhani, F., Nurul Absar, M.M. (2018). Mediating Effect of Organizational Commitment Between Islamic Human Resource Practices and Organizational Performance Among Islamic Banks of Bangladesh. The Journal of Muamalat and Islamic Finance Research, Vol. 15(2), 54-65.

Mahesar, H.A., Chaudhry, N.I., Ansari, M.A. and Ali Nizar, Q. (2016). Do Islamic HRM Practices Influence Employee Outcomes: Mediating Role of Employee Engagement. International Research Journal of Arts and Humanities.

Mansoor Ahmad \& Matthew Allen (2015). High Performance HRM And Establishment Performance in Pakistan: An Empirical Analysis, Employee Relations, Vol. 37(5), 506 - 524.

Mohd Said, N. (2015). Faktor-faktor yang mempengaruhi amalan pengurusan sumber manusia Islam: kajian kes Felda Holding Bhd Wilayah Alor Setar. Disertasi Sarjana Sains (Pengurusan), Universiti Utara Malaysia, Kedah.

Muafi, and Qurotul Uyun (2018). The Influence of Islamic HRM Practices On Organizational Learning And Its Impact On Environmental, Social And Religious. Performance Journal of Entrepreneurship Education, 21(IS). https://www.abacademies.org/articles/the-influence-of-islamic-hrm-practices-on-organizational-learning-andits-impact-on-environmental-social-and-religious-performance7270.html

Muhammad Habib Ahmad (2015). Impact of HR practices on organizational performance: Islamic principles as moderator. M.Phil Dissertation. Bahauddin Zakariya University, Pakistan. 


\section{Ilhaamie Abdul Ghani Azmi 78}

Mulgan, G. (2014). Innovation in the public sector: how can public organisations better create, improve, and adapt? London: Nesta. See: http://www.nesta.org.uk/sites/default/files/innovation_in_the_public_sector-_how_can_public_organisations_better_create_improve_and_adapt.pdf

Nik Ab, Rahman, N.M., Shahid, S. and Alam, S.S. (2011). Relationship Between Islamic HRM Practices and Employee Commitment: An Empirical Study of Islamic Banks in Bangladesh. Journal of Applied Sciences Research, Vol. 7(8), 1269-1278.

Nik Ab. Rahman, N.M., Alias, M.A., Shahid, S., Abdul Hamid, M., Alam, S.S. (2013). Relationship Between Islamic Human Resource Management (IHRM) Practices and Trust: An Empirical Study. Journal of Industrial Engineering and Management JIEM, Vol. 6(4), 11051123.

Rana Riaz Ahmad, M.H.A. (2015). Impact of HR practices on performance: moderating role of Islamic principles. M. Phil. in Business Administration Dissertation, Bahauddin Zakariya University, $\mathrm{Pa}-$ kistan.

Ramli, R.I. A, Abu-Hassan, N., Arifin, A.S. and Jasmid, A.N. (2017). Implementation Of Policy Initiatives to Foster Public Sector Innovation In Malaysia: The Need For Measurement, JOSTIP, Vol. 3(1), 23-29.

Osman, I., Mahphoth, M.H., Hashim, J. M. (2012). "Human Resource Management from an Islamic Perspective: Experiences of GLCs." The International Conference on Science, Technology and Social Sciences (ICSTSS) 2012, Pahang, Malaysia.

Osman, I., Mahphoth, M.H., Hashim, J. M., Omar, R. (2014). "Islamic perspective of human talent identification and organizational justice: evidence from Government-Linked Companies in Malaysia." The 1st ICIBACC 2014, Melaka, Malaysia. 


\section{Islamic Human Resource Management Practices and Innovation in}

Malaysian Public Service

Siswanto. (2014). Improving Competitiveness of Islamic Banking Human Resources Through Implementation Of Quran-Based HRM Practices. European Journal of Business and Social Sciences, Vol. 3(3), $1-13$.

Yusof, A.A. \& Dwi Sari, M. (2017). Pembangunan Modal Insan Daripada Perspektif Islam: Impak Kepada Pengurus. Malaysian Journal of Social Sciences and $\mathrm{H}$ 